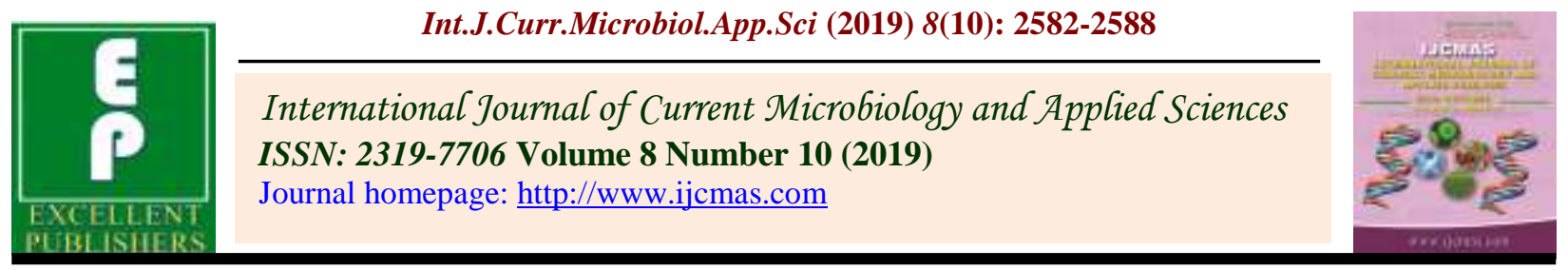

Original Research Article

https://doi.org/10.20546/ijcmas.2019.810.299

\title{
Influence of Nutrients and Shoot Retention on Growth, Yield and Fruit Characters in Rejuvenated Guava (Psidium guajava L.) cv. Sardar
}

\author{
S. Archana ${ }^{*}$, Nagesh Naik ${ }^{2}$, K.H. Nataraja ${ }^{3}$, V. Kantharaju ${ }^{4}$, \\ Sayeed Almas Mulla ${ }^{5}$ and V. Vandana ${ }^{6}$ \\ ${ }^{1,2,3}$ Department of Fruit Science, ${ }^{4}$ Department of Plant pathology, ${ }^{5}$ Department of Soil \\ Science, ${ }^{4}$ Department of SAS, Kittur Rani Channamma College of Horticulture, Arabhavi, \\ Gokak, Tq. Belagavi, D. Karnataka, India
}

*Corresponding author

\section{Keywords}

Guava,

Rejuvenation, Shoot retention, Nutrients

\section{Article Info}

Accepted:

18 September 2019

Available Online:

10 October 2019

\section{A B S T R A C T}

A study on the influence of nutrients and shoot retention on growth and yield in rejuvenated guava was conducted during 2018-2019 in the Department of Fruit Science, Kittur Rani Channamma College of Horticulture, Arabhavi (UHS, Bagalkot), Karnataka. Among shoot thinning 3 shoots per branch $\left(S_{1}\right)$ recorded maximum plant height $(3.16 \mathrm{~m})$, length of the shoot $(132.48 \mathrm{~cm})$, girth of the shoot $(3.09 \mathrm{~cm})$, number of leaves per shoot (76.94), Plant spread (N-S and E-S) (3.30 and $3.44 \mathrm{~m}$ ), fruit physical parameters viz., Fruit length $(6.48 \mathrm{~cm})$, girth $(6.58 \mathrm{~cm})$, weight $(162.82 \mathrm{~g})$,number of fruits per plant $(69.28)$, yield $(2.85 \mathrm{t} / \mathrm{ha})$. Nutrient had significant effect on growth and yield parameters in rejuvenated guava. Plants supplemented with $100 \%$ RDF (200: 80: 150 NPK g/plant) + $(\mathrm{Zn}+\mathrm{B}+\mathrm{Mg}) 0.3 \%$ each $\left(\mathrm{F}_{6}\right)$ has recorded maximum plant height $(3.11 \mathrm{~m})$, length of the shoot $(133.22 \mathrm{~cm})$, girth of the shoot $(3.00 \mathrm{~cm})$, number of leaves per shoot $(76.00)$, Plant spread (N-S and E-S) (3.25 and $3.32 \mathrm{~m})$, fruit physical parameters viz., Fruit length (6.57 $\mathrm{cm})$, girth $(6.64 \mathrm{~cm})$, weight $(168.64 \mathrm{~g})$, number of fruits per plant (69.14), yield (3.03 $\mathrm{t} / \mathrm{ha}$ ). Interaction effect has got non significant results for all the parameters. However, the treatment $\mathrm{S}_{2} \mathrm{~F}_{6}$ consisting of 4 shoots per branch and 100 per cent RDF (200:80:150 NPK $\mathrm{g} / \mathrm{plant})+(\mathrm{Zn}+\mathrm{B}+\mathrm{Mg}) 0.3$ per cent each has recorded moderate vegetative and fruit physical parameters and highest leaves per plant (79.67), highest number of fruits per plant (73.96) and yield (3.30 t/ha) with highest benefit cost ratio of 2.02 .

\section{Introduction}

Guava (Psidium guajava L.) is one of the most exquisite and valuable fruit of the tropics and belongs to the family "Myrtaceae". It is native of Tropical America and brought to India by the Portuguese as early as $17^{\text {th }}$ century. Guava is considered to be poor man's fruit and also called as apple of tropics which is very nutritious having vitamin C (75-260 mg/100g pulp) (Shukla et al., 2008). Fruits are preferred for fresh consumption as well as different 
processed products like jam, jelly, cheese, nectar etc. All parts of the plant used for different medicinal purposes viz., hepatoprotection, antioxidant, antiinflammatory, antispasmodic, anti-cancer, antimicrobial, anti-hyperglycemic, analgesic, anti-stomachache and anti-diarrhea (Barbalho et al., 2012). In order to overcom the problem of unproductive and uneconomic orchards existing in abundance, large scale uprooting and replacement with new plantations (rehabilitation) is long term and expensive strategy. The rejuvenation technology involves the heading back of exhausted trees (showing marked decline in annual production and quality of produce) to 1.0 to 1.5 -meter height above the ground level during MayJune or December-February to facilitate the production of new shoots from below the cut point and allow the development of fresh canopy of healthy shoots (Jahangeer et al., 2011). Pruning helps to balance between vegetative and reproductive growth of the plant. The main advantages of pruning on bearing trees include the formation of new shoots, avoid overcrowding of branches, removal of criss-crossed and diseased branches (Lian et al., 2019). Manipulation of tree growth using canopy management practices to control tree growth patterns, tree shape for high fruit production of desired size and quality (Singh, 2001). The thinning of shoots per branch is also one of the canopy management practices in the rejuvenation of old orchards (Bhagawati et al., 2015). Nutrients can be made available to the plants by the basal as well as foliar application. Nitrogen, phosphorus and potassium are the major and essential nutrients required by the plants in larger quantities. These are responsible for maximizing physiological activities of the plant which ultimately affect the growth, development, fruiting and quality until the fruits attain physiological maturity (Nijjar, 1996). Hence, the present investigation was undertaken to study the influence of nutrients and shoot retention on growth, yield in rejuvenated guava cv. Sardar.

\section{Materials and Methods}

An experiment was carried out in the fruit science departmental orchard, the experiment was laid out in factorial randomized completely block design (FRCBD) and replicated thrice as follows. The factor 1 consists of 3 levels of thinning, i.e. retaining three shoots per branch $\left(S_{1}\right)$, four shoots per branch $\left(\mathrm{S}_{2}\right)$ and Five shoots per branch $\left(\mathrm{S}_{3}\right)$. Shoot thinning was done in the $1^{\text {st }}$ week of June. Factor 2 consists of 6 different nutrient levels viz., $50 \%$ RDF (100: 40: 75 NPK $\mathrm{g} /$ plant $)+(\mathrm{Zn}+\mathrm{B}+\mathrm{Mg}) 0.2 \%$ each $\left(\mathrm{F}_{1}\right), 50 \%$ RDF (100: 40: 75 NPK g/plant) $+(\mathrm{Zn}+\mathrm{B}+\mathrm{Mg})$ $0.3 \%$ each $\left(\mathrm{F}_{2}\right), 75 \%$ RDF (150: 60: 110 NPK g/plant $)+(\mathrm{Zn}+\mathrm{B}+\mathrm{Mg}) 0.2 \%$ each $\left(\mathrm{F}_{3}\right)$, $75 \%$ RDF (150: 60: 110 NPK g/plant) + $(\mathrm{Zn}+\mathrm{B}+\mathrm{Mg}) \quad 0.3 \%$ each $\left(\mathrm{F}_{4}\right), 100 \% \mathrm{RDF}$ (200: 80: 150 NPK g/plant) + (Zn+B+Mg) 0.2 $\%$ each $\left(\mathrm{F}_{5}\right), 100 \%$ RDF (200: 80: 150 NPK g/plant $)+(\mathrm{Zn}+\mathrm{B}+\mathrm{Mg}) 0.3 \%$ each $\left(\mathrm{F}_{6}\right)$. Recommended doses of fertilizers were applied on per plant basis according to the treatment details in two split doses. 50 per cent of urea was applied in the month of July as basal dose and the remaining 50 per cent urea and full dose of single super phosphate and muriate of potash as top dress applied during October. Micro nutrients like zinc in the form of $\mathrm{ZnSo}_{4}$, boron in the form of borax and magnesium in the form of $\mathrm{MgSo}_{4}$ sprayed before and after flowering as per the treatments.

\section{Results and Discussion}

The growth parameters were significantly influenced by different treatments. Plants retained with 3 shoots per branch had resulted in maximum plant height $(3.16 \mathrm{~m})$, plant girth $(12.01 \mathrm{~cm})$, length of the shoot $(132.48 \mathrm{~cm})$, girth of the shoot $(3.09 \mathrm{~cm})$ this may be 
attributed to relatively less numbers of shoots and availability of more nutrients per shoots under identical condition which is also reported by Bhagawati et al., (2015) in guava. In the present study lateral buds are stimulated to grow (due to better dry matter partitioning) after pruning due to higher activity of GA-like substances which can be related to the findings by Lian et al., (2019) in guava. Further higher number of leaves per shoot (76.94) was recorded in 4 shoots per branch which is due to increased length of shoot with the increasing pruning severity which was also reported by Pawan et al., (2017) in mulberry. Maximum plant spread (N-S and E-W) (3.30 and $3.44 \mathrm{~m})$ canopy volume $\left(11.52 \mathrm{~m}^{3}\right)$ were recorded in 5 shoots per branch. Since, pruning remove carbon-starved, fruiting exhausted shoots and promotes new leaf growth to build-up carbohydrates reserves for the next flowering and allows the sprouting of lateral buds which ultimately influenced the canopy spread and volume which was reported by Dhaliwal et al., (2000) and Pilania et al., (2010) in guava. Among nutrition $\mathrm{F}_{6}$ has recorded maximum vegetative parameters viz., plant height $(3.11 \mathrm{~m})$, plant girth $(11.74 \mathrm{~cm})$, length of the shoot $(133.22 \mathrm{~cm})$, girth of the shoot $(3.00 \mathrm{~cm})$, number of leaves per shoot (76.00), Plant spread (N-S and E-S) (3.25 and $3.32 \mathrm{~m})$ and canopy volume $\left(10.82 \mathrm{~m}^{3}\right)$. This might be due to the fact that, application of nitrogen which resulted in vigorous vegetative growth of the plant and gave the darker green colour to the foliage. This favoured the photosynthetic activity of the plants and greater synthesis of carbohydrates, which led to the formation of amino acids, nucleoproteins, chlorophyll, alkaloids and amides. The complex compounds are responsible for building up of new tissues and are associated with a number of metabolic processes, which in turn favour better developments of plants. The increase in growth as a result of nitrogen application is obvious. Similarly, increase in vegetative growth of fruit plants by the application of nitrogen has also been reported earlier by Dhomane et al., (2011) and Dineshkumar et al., (2009) in guava. Increased vegetative growth by micronutrients might be due to residual effect of higher concentration of auxins in plant which produced high leaf to fruit ratio was an ultimate cause of higher amount of photosynthates and has a key role in cell division and elongation, and there by increased vegetative growth.

The highest Fruit length $(6.48 \mathrm{~cm})$, girth $(6.58$ $\mathrm{cm})$, weight $(162.82 \mathrm{~g})$ and volume (139.53 $\mathrm{ml}$ ) was recorded in $\mathrm{S}_{1}$. The results are in the confirmation with Dhaliwal et al., (2000) in guava, they found that polar diameter of fruit increased with pruning intensity of guava and also by Pilania et al., (2010) in guava. The higher fruit weight and volume in pruned plants may be due to an improved microclimate and higher photosynthetic rates as the pruning intensity increases the number of fruits per plant decreases. So, developing fruit gets ample of nutrient and plant hormone that increases fruit size. This may be the reason of highest fruit weight and volume observed in severe pruning by Sahoo et al., (2017) in Sapota. Among the nutrition highest fruit length $(6.57 \mathrm{~cm})$, girth $(6.64 \mathrm{~cm})$, weight $(168.64 \mathrm{~g})$ and volume $(146.70 \mathrm{ml})$ was recorded in $\mathrm{F}_{6}$. The increase in number and area of leaves increases the amount of photosynthates that cause a significant increase in size and weight of fruit. The results of the present findings are supported from the findings of Lian et al., (2019) in guava. This is due to the fact that nitrogen increases the efficiency of metabolic processes of the plant and consequently increases the size and weight of the fruit, another probable cause could be greater mobility of nutrients to the developing fruits which act as strong metabolic sink. Similar results were also reported by Dineshkumar et al., (2009) in guava (Table 1 and 2). 
Table.1 Estimation of vitamin B-6 (ppm) in Areca nut collected from different locations of Karnataka

\begin{tabular}{|c|c|c|c|c|c|c|c|c|}
\hline \multirow[t]{2}{*}{ Treatments } & \multirow{2}{*}{$\begin{array}{c}\text { Plant } \\
\text { height } \\
\text { (cm) }\end{array}$} & \multirow{2}{*}{$\begin{array}{l}\text { Plant } \\
\text { stem } \\
\text { girth } \\
\text { (cm) }\end{array}$} & \multirow{2}{*}{$\begin{array}{l}\text { Length } \\
\text { of the } \\
\text { shoots } \\
(\mathrm{cm})\end{array}$} & \multirow{2}{*}{$\begin{array}{c}\text { Girth of } \\
\text { the } \\
\text { shoots } \\
\text { (cm) }\end{array}$} & \multirow{2}{*}{$\begin{array}{c}\text { Number } \\
\text { of leaves } \\
\text { per } \\
\text { shoots }\end{array}$} & \multicolumn{2}{|c|}{ Plant spread (m) } & \multirow{2}{*}{$\begin{array}{c}\text { Canopy } \\
\text { volume } \\
\left(\mathbf{m}^{\mathbf{3}}\right)\end{array}$} \\
\hline & & & & & & $\begin{array}{l}\text { (North- } \\
\text { South) }\end{array}$ & $\begin{array}{l}\text { (East- } \\
\text { West) }\end{array}$ & \\
\hline \multicolumn{9}{|c|}{ Shoots retention $(\mathbf{S})$} \\
\hline $\mathbf{S}_{1}$ & 3.16 & 12.01 & 132.48 & 3.09 & 71.07 & 2.80 & 2.80 & 8.02 \\
\hline $\mathbf{S}_{2}$ & 2.89 & 11.65 & 127.02 & 2.66 & 76.94 & 3.03 & 3.19 & 10.08 \\
\hline $\mathbf{S}_{3}$ & 2.69 & 10.43 & 123.11 & 2.47 & 71.41 & 3.30 & 3.44 & 11.52 \\
\hline S.Em \pm & 0.06 & 0.22 & 1.60 & 0.063 & 1.31 & 0.05 & 0.05 & 0.24 \\
\hline CD at $5 \%$ & 0.16 & NS & 4.60 & 0.18 & NS & 0.15 & 0.15 & 0.69 \\
\hline \multicolumn{9}{|l|}{ Nutrition (F) } \\
\hline $\mathbf{F}_{1}$ & 2.77 & 10.85 & 122.94 & 2.51 & 70.72 & 2.84 & 2.98 & 8.88 \\
\hline $\mathbf{F}_{2}$ & 2.83 & 11.23 & 124.89 & 2.63 & 71.26 & 2.88 & 3.06 & 9.40 \\
\hline $\mathbf{F}_{3}$ & 2.87 & 11.32 & 126.41 & 2.71 & 72.28 & 2.97 & 3.10 & 9.75 \\
\hline $\mathbf{F}_{4}$ & 2.93 & 11.50 & 127.57 & 2.76 & 73.43 & 3.10 & 3.16 & 9.99 \\
\hline $\mathbf{F}_{5}$ & 2.97 & 11.55 & 130.18 & 2.84 & 75.13 & 3.21 & 3.25 & 10.41 \\
\hline $\mathbf{F}_{6}$ & 3.11 & 11.74 & 133.22 & 3.00 & 76.00 & 3.25 & 3.32 & 10.82 \\
\hline S.Em \pm & 0.08 & 0.31 & 2.26 & 0.089 & 1.85 & 0.08 & 0.07 & 0.34 \\
\hline CD at $5 \%$ & 0.23 & 0.89 & 6.50 & 0.25 & 5.32 & 0.22 & 0.21 & 0.98 \\
\hline \multicolumn{9}{|c|}{ Interactions $(\mathrm{S}$ x F) } \\
\hline$S_{1} F_{1}$ & 3.06 & 11.02 & 128.33 & 2.91 & 68.50 & 2.55 & 2.58 & 6.92 \\
\hline$S_{1} F_{2}$ & 3.11 & 11.93 & 130.00 & 2.97 & 69.37 & 2.60 & 2.67 & 7.17 \\
\hline$S_{1} F_{3}$ & 3.13 & 11.93 & 130.83 & 3.04 & 70.00 & 2.77 & 2.76 & 7.83 \\
\hline$S_{1} F_{4}$ & 3.17 & 12.23 & 133.00 & 3.13 & 71.13 & 2.89 & 2.81 & 8.20 \\
\hline $\mathbf{S}_{\mathbf{1}} \mathbf{F}_{5}$ & 3.20 & 12.24 & 135.05 & 3.20 & 73.40 & 2.96 & 2.97 & 8.67 \\
\hline$S_{1} F_{6}$ & 3.29 & 12.70 & 137.67 & 3.30 & 74.00 & 3.02 & 3.01 & 9.35 \\
\hline $\mathbf{S}_{2} \mathbf{F}_{1}$ & 2.70 & 11.44 & 122.83 & 2.44 & 74.67 & 2.89 & 3.07 & 9.54 \\
\hline $\mathbf{S}_{2} \mathbf{F}_{2}$ & 2.79 & 11.45 & 124.67 & 2.58 & 75.00 & 2.92 & 3.13 & 9.64 \\
\hline $\mathbf{S}_{2} \mathbf{F}_{3}$ & 2.83 & 11.69 & 126.39 & 2.63 & 76.50 & 2.93 & 3.16 & 9.91 \\
\hline $\mathbf{S}_{2} \mathbf{F}_{4}$ & 2.91 & 11.76 & 127.38 & 2.65 & 77.49 & 3.00 & 3.20 & 10.17 \\
\hline $\mathbf{S}_{2} \mathbf{F}_{5}$ & 2.96 & 11.75 & 128.49 & 2.73 & 78.33 & 3.20 & 3.25 & 10.38 \\
\hline$S_{2} F_{6}$ & 3.17 & 11.83 & 132.33 & 2.93 & 79.67 & 3.23 & 3.32 & 10.85 \\
\hline $\mathbf{S}_{3} \mathbf{F}_{1}$ & 2.55 & 10.08 & 117.67 & 2.17 & 69.00 & 3.06 & 3.28 & 10.18 \\
\hline$S_{3} F_{2}$ & 2.60 & 10.31 & 120.00 & 2.34 & 69.40 & 3.13 & 3.37 & 11.39 \\
\hline $\mathbf{S}_{\mathbf{3}} \mathbf{F}_{\mathbf{3}}$ & 2.64 & 10.33 & 122.00 & 2.46 & 70.34 & 3.20 & 3.38 & 11.51 \\
\hline $\mathbf{S}_{3} \mathbf{F}_{4}$ & 2.71 & 10.49 & 122.33 & 2.48 & 71.68 & 3.40 & 3.46 & 11.61 \\
\hline $\mathbf{S}_{3} \mathbf{F}_{5}$ & 2.75 & 10.67 & 127.00 & 2.59 & 73.67 & 3.47 & 3.54 & 12.18 \\
\hline$S_{3} F_{6}$ & 2.86 & 10.68 & 129.67 & 2.77 & 74.35 & 3.50 & 3.61 & 12.26 \\
\hline S.Em \pm & 0.14 & 0.54 & 3.92 & 0.15 & 3.21 & 0.13 & 0.12 & 0.59 \\
\hline CD at $5 \%$ & NS & NS & NS & NS & NS & NS & NS & NS \\
\hline
\end{tabular}


Table.2 Influence of number of shoots and nutrients on yield and yield attributes in rejuvenated guava

\begin{tabular}{|c|c|c|c|c|c|c|c|c|}
\hline \multirow[t]{2}{*}{ Treatments } & \multicolumn{4}{|c|}{ Fruit } & \multirow{2}{*}{$\begin{array}{c}\text { Number } \\
\text { of fruits } \\
\text { per plant }\end{array}$} & \multicolumn{2}{|c|}{ Yield } & \multirow{2}{*}{$\begin{array}{l}\text { B:C } \\
\text { Ratio }\end{array}$} \\
\hline & $\begin{array}{l}\text { Length } \\
\text { (cm) }\end{array}$ & $\begin{array}{l}\text { Girth } \\
\text { (cm) }\end{array}$ & $\begin{array}{l}\text { Weight } \\
\text { (g) }\end{array}$ & $\begin{array}{l}\text { Volume } \\
\text { (ml) }\end{array}$ & & (kg/plant) & (t/ha) & \\
\hline \multicolumn{9}{|c|}{ Shoots retention (S) } \\
\hline$S_{1}$ & 6.48 & 6.58 & 162.82 & 139.53 & 61.71 & 9.17 & 2.55 & - \\
\hline $\mathbf{S}_{2}$ & 6.29 & 6.38 & 157.89 & 136.27 & 69.28 & 10.25 & 2.85 & - \\
\hline $\mathbf{S}_{3}$ & 5.93 & 6.10 & 147.98 & 123.04 & 65.48 & 9.23 & 2.57 & - \\
\hline S.Em \pm & 0.08 & 0.08 & 3.01 & 3.07 & 0.85 & 0.23 & 0.064 & - \\
\hline CD at $5 \%$ & 0.22 & 0.24 & 8.66 & 8.82 & 2.45 & 0.66 & 0.18 & - \\
\hline \multicolumn{9}{|l|}{ Nutrition (F) } \\
\hline$F_{1}$ & 5.98 & 6.08 & 143.59 & 123.52 & 61.02 & 8.31 & 2.31 & - \\
\hline $\mathbf{F}_{2}$ & 6.06 & 6.21 & 150.12 & 127.48 & 63.03 & 8.81 & 2.45 & - \\
\hline $\mathbf{F}_{3}$ & 6.14 & 6.28 & 152.74 & 129.62 & 65.43 & 9.35 & 2.60 & - \\
\hline $\mathbf{F}_{4}$ & 6.25 & 6.39 & 158.26 & 131.21 & 66.52 & 9.73 & 2.70 & - \\
\hline$F_{5}$ & 6.39 & 6.51 & 164.03 & 139.14 & 67.80 & 10.20 & 2.83 & - \\
\hline $\mathbf{F}_{6}$ & 6.57 & 6.64 & 168.64 & 146.70 & 69.14 & 10.90 & 3.03 & - \\
\hline S.Em \pm & 0.11 & 0.12 & 4.26 & 4.34 & 1.20 & 0.33 & 0.091 & - \\
\hline CD at $5 \%$ & 0.32 & 0.33 & 12.25 & 12.47 & 3.46 & 0.94 & 0.26 & - \\
\hline \multicolumn{9}{|c|}{ Interactions (S x F) } \\
\hline$S_{1} F_{1}$ & 6.20 & 6.30 & 147.40 & 129.00 & 58.73 & 8.04 & 2.23 & 0.61 \\
\hline $\mathbf{S}_{1} \mathbf{F}_{2}$ & 6.28 & 6.44 & 154.92 & 132.22 & 59.70 & 8.63 & 2.40 & 1.02 \\
\hline $\mathbf{S}_{\mathbf{1}} \mathbf{F}_{\mathbf{3}}$ & 6.29 & 6.57 & 156.01 & 134.97 & 61.41 & 8.93 & 2.48 & 1.04 \\
\hline $\mathbf{S}_{1} \mathbf{F}_{4}$ & 6.42 & 6.63 & 166.45 & 136.53 & 61.83 & 9.27 & 2.58 & 1.42 \\
\hline $\mathbf{S}_{1} \mathbf{F}_{5}$ & 6.74 & 6.70 & 175.07 & 148.33 & 63.47 & 9.71 & 2.70 & 1.48 \\
\hline$S_{1} F_{6}$ & 6.95 & 6.84 & 177.08 & 156.11 & 65.12 & 10.41 & 2.89 & 1.64 \\
\hline $\mathbf{S}_{2} \mathbf{F}_{1}$ & 6.08 & 6.14 & 146.03 & 128.22 & 64.13 & 8.80 & 2.44 & 0.77 \\
\hline $\mathbf{S}_{2} \mathbf{F}_{2}$ & 6.13 & 6.26 & 149.40 & 131.11 & 65.82 & 9.16 & 2.55 & 0.84 \\
\hline $\mathbf{S}_{2} \mathbf{F}_{3}$ & 6.23 & 6.32 & 156.45 & 132.22 & 68.83 & 10.09 & 2.80 & 1.31 \\
\hline$S_{2} F_{4}$ & 6.35 & 6.39 & 158.67 & 134.22 & 70.48 & 10.46 & 2.90 & 1.38 \\
\hline$S_{2} F_{5}$ & 6.40 & 6.53 & 166.33 & 140.75 & 72.45 & 11.15 & 3.10 & 1.84 \\
\hline$S_{2} F_{6}$ & 6.53 & 6.62 & 170.43 & 151.09 & 73.96 & 11.87 & 3.30 & 2.02 \\
\hline $\mathbf{S}_{3} \mathbf{F}_{1}$ & 5.66 & 5.80 & 137.34 & 113.33 & 60.18 & 8.10 & 2.25 & 0.63 \\
\hline $\mathbf{S}_{3} \mathbf{F}_{2}$ & 5.78 & 5.93 & 146.02 & 119.11 & 63.58 & 8.64 & 2.40 & 0.73 \\
\hline $\mathbf{S}_{\mathbf{3}} \mathbf{F}_{\mathbf{3}}$ & 5.90 & 5.96 & 145.77 & 121.67 & 66.05 & 9.03 & 2.51 & 0.77 \\
\hline $\mathbf{S}_{3} \mathbf{F}_{4}$ & 5.97 & 6.13 & 149.67 & 122.89 & 67.24 & 9.47 & 2.63 & 0.85 \\
\hline$S_{3} F_{5}$ & 6.03 & 6.31 & 150.68 & 128.33 & 67.48 & 9.74 & 2.71 & 1.48 \\
\hline$S_{3} F_{6}$ & 6.23 & 6.45 & 158.40 & 132.89 & 68.36 & 10.42 & 2.89 & 1.64 \\
\hline S.Em \pm & 0.19 & 0.20 & 7.38 & 7.52 & 2.08 & 0.57 & 0.16 & - \\
\hline CD at $5 \%$ & NS & NS & NS & NS & NS & NS & NS & - \\
\hline
\end{tabular}


The possible reason for increase in fruit weight by the micronutrients might be due to faster loading and mobilization of photo assimilates to fruits and involvement in cell division and cell expansion which ultimately reflected into more weight of fruit in treated pants. Similar results were also found by Chandra and Singh (2015) in Aonla. The highest number of fruits per plant (69.28) and yield $(10.25 \mathrm{~kg} / \mathrm{plant}$ and $2.85 \mathrm{t} / \mathrm{ha})$ was observed in $S_{2}$. Pruning facilitates supply of adequate nutrients to reduced plant parts for their proper growth and development. Thus, pruning with appropriate intensity, not only regulate the canopy size but also leads to better fruit quality and yield through better exposure of branches and fruits which was in accordance with the findings by Bhagawati et al., (2015) and Camus et al., (2018) in guava.

The analysed results dissipated significant differences for nutrition. The highest number of fruits per plant (69.14) and yield (10.90 $\mathrm{kg} /$ plant and $3.03 \mathrm{t} / \mathrm{ha}$ ) was obtained in $\mathrm{F}_{6}$. This may be due to increased photosynthesis, better plant growth and dry matter accumulation in addition to increase in number of flowers and fruit volume and fruit weight by Cardoso et al., (2011), Dineshkumar et al., (2009) in guava. Micronutrients improve physiological activities and might have improved radial and polar diameter of fruit which ultimately increased the yield of fruit. These results are in conformity with the findings of Kabeel et al., (2013) in plum. Interaction effect has got non significant results for all the parameters. However, the treatment $\mathrm{S}_{2} \mathrm{~F}_{6}$ consisting of 4 shoots per branch and 100 per cent RDF $(200: 80: 150$ NPK g/plant $)+(\mathrm{Zn}+\mathrm{B}+\mathrm{Mg}) 0.3$ per cent each has recorded moderate vegetative, fruit physical parameters and with highest leaves per plant (79.67), highest number of fruits per plant (73.96) and yield $(11.87 \mathrm{~kg} /$ plant and $3.30 \mathrm{t} / \mathrm{ha})$. The data on cost of cultivation calculated per hectare basis revealed that the treatment combination of $\mathrm{S}_{2} \mathrm{~F}_{6}$ has result the highest benefit cost ratio of 2.02. These reports are in line with the findings of Pilania et al., (2010) in guava.

In conclusion, plants with 3 shoots per branch have highest vegetative growth viz., plant height, plant girth, length and girth of the shoot. Higher number of leaves per shoot was noticed in moderately (4 shoots/branch) thinned plants and plants with 5 shoots per branch had higher canopy spread and volume. Plants received with 100 per cent RDF $(200: 80: 150 \mathrm{NPK}$ g/plant $)+(\mathrm{Zn}+\mathrm{B}+\mathrm{Mg}) 0.3$ per cent each has maximum growth and yield parameters. Retaining of 4 shoots per branch along with application of 100 per cent RDF (200:80:150 NPK g/plant $)+(\mathrm{Zn}+\mathrm{B}+\mathrm{Mg}) 0.3$ per cent each is better for higher yield with highest benefit cost ratio of 2.02 in rejuvenated guava.

\section{References}

Barbalho, S. M., Flavia, M. V., Machado, F., Goulart, R. D. A., Brunnati, A. C. S., Ottoboni, A. M. M. B. and Nicolau, C. C. T., 2012, Psidium guajava (Guava): A Plant of Multipurpose Medicinal Applications. MAP an open Access Journal, 1:4 http://dx.doi.org/10.4172/ 2167-0412.1000104.

Bhagawati, R., Bhagawati, K., Choudhary, V. K., Rajkhowa, D. J. and Sharma, R., 2015, Effect of Pruning Intensities on the Performance of Fruit Plants under Mid-Hill Condition of Eastern Himalayas. Int. Letters of Natural Sci., 46(1): 46-51.

Camus, D. D., Chinchmalatpure, A. R., Kumar, S., Prasad, I. and Vibhute, S., 2018, Pruning, irrigation and nitrogen interactions on guava yield and quality in saline vertisols. J. Soil Salin. Water Qual., 10(2): 212-217.

Cardoso, E., Costa, de A., Soares, J. T. A., 
Silva, I. S., Da, R. M. and Maracaja P. B., 2011, Productivity of guava 'Paluma' for each of mineral fertilization. Revista Verde de Agroecologiae desenvolvimento Sustentavel, 6(2): 149-153.

Chandra, R. and Singh, K. K., 2015, Foliar application of zinc sulphate, magnesium sulphate and copper sulphate on the yield and quality of aonla (Emblica officinallis Gaerth L.) cv. "NA-7" under Garhwal Himalayas. J. Medicinal Plants Studies, 3(5): 42-45.

Dhaliwal, G. S., Rattanpal, H. S. and Gill, H. S., 2000, Effect of time and severity of pruning on cropping and physicochemical properties of 'Sardar' guava. Haryana J. Hort. Sci., 29: 20-27.

Dhomane, P. A., Kadam, A. S., Lakade, S. K. and Gharge, V. R., 2011, Effect of different sources of nitrogen on growth and yield of guava cv. Sardar. Asian J. Hort., 6(1): 92-95.

Dineshkumar, V., Pandey, K., Anjaneyulu and Vishal Nath, 2009, Optimization of major nutrients for guava yield and quality under East coastal conditions. Indian J. Hort., 66 (1): 18-21.

Jahangeer, A., Baba, P., Akbar, I. and Kumar, V., 2011, Rejuvenation of old and senile orchards: A review. Ann. Hort., 4(1): 37-44.

Kabeel, H., Somia, A., Fawaz, E. A., Ismail and Khalaf, A. F. A., 2013, Effect of calcium and boron foliar spray on fruit quality and leaf nutritional status of "Kelsey" plum trees Egypt. J. Hort., 40(1): 19-36.

Lian, H. N., Singh, B., Senjam, B. D. and
Ramjan, M., 2019, Effect of shoot pruning on growth and yield of guava (Psidium guajava L.) cv. L-49 under foothills of Arunachal Pradesh. Int. J. Curr. Microbiol. App. Sci., 8(3): 20202027.

Nijjar, G S., 1996, Nutrition of fruit trees. Kalyani publishers, New Delhi, Ludhiana, pp. 6-9.

Pawan, S. J. R., Satpal, B., Surinder, S. and Mukesh, K., 2017, Effect of the time and severity of pruning on growth, yield and quality in mulberry (Morus alba L.). Int. J. Agri. Sci., 9(50): 4861-4863.

Pilania, S., Shukla, A. K., Maheswar, L. N., Sharma, R. and Bairwa., H. L., 2010, Standardization of pruning intensity and integrated nutrient management in meadow orcharding of guava (Psidium guajava). Indian J. Agri. Sci., 80(8):673-678.

Sahoo, A. K., Tarai, R. K., Dash, D. K., Shinde, G. S. and Bhusan, L. P., 2017, Effect of different level of pruning on growth, yield and fruit quality of sapota cv. Cricket ball under coastal zone of Odisha. Int. J. Chem. Studies, 5(6): 2157-2160.

Shukla, A.K., Kaushik, R.A., Devendra, P. and Sarolia, D. K., 2008, Guava technical bulletin No.1. Communication centre, Directorate of extension education. MPUAT, Udaipur, $\mathrm{p}-1$.

Singh, G., 2001, High density planting in guava. Annual Report, Central Institute of Subtropical Horticulture, Lucknow.

\section{How to cite this article:}

Archana, S., Nagesh Naik, K.H. Nataraja, V. Kantharaju, Sayeed Almas Mulla and Vandana, V. 2019. Influence of Nutrients and Shoot Retention on Growth, Yield and Fruit Characters in Rejuvenated Guava (Psidium guajava L.) cv. Sardar. Int.J.Curr.Microbiol.App.Sci. 8(10): 2582-2588. doi: https://doi.org/10.20546/ijcmas.2019.810.299 